\title{
O MUNDO DAS SOMBRAS NA POESIA LATINA
}

\author{
Zélia de Almeida Cardoso \\ Universidade de Sáo Paulo
}

Abstract

The supposition that the life of the soul goes after the death of the body glves origin to myths tying to outline the abode of spirts. As $\mathbf{H}$ occurs in all clulizations, we also find the myth of hell among the anclent Romans. In spite of being an allen myth It was extensively used in the wittings of Lath authors. We compare the chilef texts which present the myth of hell and emphesize the desciption found in the sixth book of the Aeneid. We attempt to detect oniginality of Virgil, making a comparison between the Kingdom of the dead in the Aeneld and its main source: the Homeric hell, found in the eleventh book of the Odyssey. The existence of so many different descriptions of hell in Lattin poetry makes us belleve that Roman witters used such a theme as a stylistic element rather than a true religlous beliet. 
A inquietaçăo coin a sobrevivência da alma esteve de alguma forma presente em todas as civilizaçסes. A impressăo de que a vida se preserva após a morte fisica năo so deu origem aos mais variados cerimoniais em homenagem aos mortos, freqüentes em todas as culturas, mesmo nas acentuadamente primitivas', como também alimentou os mitos que procuram configurar o "local" onde as almas se reúnem, após a morte do corpo.

Entre as antigas civilizaçoes historicas, a crença na sobrevida foi constante. Desnecessário serla falar, por exemplo, do papel que desempenhou, na cultura egípcia, a certeza da sobrevivencia do espirtto. O embalsamamento e a mumificaçăo/do corpo, - complicado ittual fúnebre, a exigência de um sem-número de providéncias relacionadas com o funeral, a edificaçăo de pirâmides, mastabas e hipogeus, utilizados como sepulcros, tudo isso acrescido à existência do famoso Livro dos Mortos leva-nos ao conhecimento do pensamento do Egito sobre a vida no além. O cadáver devia ser tratado para que a alma do morto se apresentasse condignamente perante os deuses. Admitia-se um julgamento final quando, após ter confessado a vida que tivera, a alma receberia o castigo ou o prêmio, passando a pertencer, neste último caso, ao mundo dos ber-aventurados ${ }^{2}$.

Também entre os hebreus houve uma crença arraigada, quanto à vida futura. Há muitas referências, no Antigo Testamento, ao enterramento de cadáveres ${ }^{3}$ - $\theta$ nesse procedimento diferenciava-se o povo de Israel do primitivos habitantes de Canaă, que praticavam a incineração dos corpos -, às homenagens feltas aos antepassados $\theta$ a castigos que puniriam os Impios após a morte. As palavras de Isalas deixam entrever um aspecto dessa crença: "Qual de vós poderá habitar em um fogo devorador? Qual de vós poderá habitar entre as chamas eternas?" (Is. XXXIII, 14).

Em Roma, salvo esporádicos casos excepcionais, a idéla de uma sobrevida fol constante, estendendo-se dos primórdios da civilizaçáo à expansáo do cristianismo $\theta$ sofrendo, a partir de tal momento, as adaptaçőes necessárias. O ritual funerário se manteve, por séculos, sem modificaçర̋es substanciais $\theta$ a própria tradiçăo religiosa mostra que a admissão da sobrevivência da alma era comum à maioria do povo ${ }^{4}$. As cinzas dos mortos, enterradas inicialmente no próprio lar $\theta$, mais tarde, em locals apropriados, fora dos muros das cidades, eram cultuadas para que, conforme se acreditava, fosse garantido descanso eterno à alma libertada do envólucro mortal. Os Manes ou espiritos dos mortos - eram reverenciados em todas as familias como verdadelras divindades e o culto a eles tributado figura entre as mais antigas formas de rituais religiosos itálicos.

O mito do reino das sombras, entretanto, tal como o conhecemos através da literatura latina, $\theta$ alienigeno. Como quase todos os mitos que se divulgam em Roma $\theta$ encontram expressáo nas obras literárias, provêm da Grécia e sofre, no processo assimilatónio, pequenas adaptaçős formais.

1 - Ct. Goody, 1962 e Banton, 1966.

2 - Ci. Challaye, 1940. Cap. III.

3 - Ver Gen. 23,1; 25,9; 35,29; 50,1 ss. e outros.

4 - Ct. Boissier, s/d: voll (intr.). 
Na Grécia Antiga, as idéias sobre a pós-vida foram diversas e contraditórias. Apesar de o pensamento mais freqüente parecer admitir a sobrevivência da alma debaixo da terra, num local especffico - o reino de Hades, descrito na Odisséia (XI) e na Teogonia (722-819) -, muito cedo a investigaçáo cientffica começa a pór dúvidas a tal crença. Dembcrito se refere às fantasias miticas sobre a vida futura5: Epicuro descre da imortalidade da alma ${ }^{6}$

O mito, contudo, tal como concebido originalmente, continua a fazer-se presente nos textos literários helenicos $\theta$, ao florescer a literatura latina, inspirada na grega, faz incursóes freqüentes nas páginas dos escritores de Roma. O tratamento do mito. porém, como tema poético de obras profundamente influencladas pela poesia da Gré cia, $\theta$ as interpretaçסes bastante particulares que gerou levam-nos a considerá-lo multo mais como artiffcio art'stico do que como correspondéncia a uma verdadeira crença.

Săo numerosos os escritores latinos que a ele se referem, oferecendo-nos "retratos" diversificados da lúgubre mansáo das almas - do chamado Império de Plutăo, que, por localizar-se, conforme se admitia, nas profundezas da terra, fol também denominado o mundo inferior, 0 inferno.

Conquanto tivesse Lucrécio, o poéta-filósofo da época de Clcero, considerado as lendas infernais como criaçరes humanas de teor alegórico, procurando mostrar que "tudo aquilo que se diz encontrar-se no profundo Aqueronte está em nossas vidas" $\theta$ insinuando que as grandes figuras infemais săo apenas simbólicas $\theta$ que $\theta$ no mundo terreno que "a vida dos insensatos se transforma em inferno". os escritores dos dias de Augusto e do século I d.C. fartaram-se de mencionar o reino dos mortos, descre vendo-o, por vezes, em precisos pormenores.

Virglio $\theta$, sem dúvida, quem nos oferece a descriçăo mals completa, consagrando todo o livro VI da Eneida à viagem de Enélas aos domínios de Plutáo. A exemplo do que fizera Homero na Odisséla, relatando a ida de Ulisses ao relno de Hades, o poeta latino constroi uma narriva detalhada, abundante em pormenores curiosos e originais que ora nos propoem indagaçoes, levando-nos a pesquisas, ora fornecem informaçoes esclarecedoras.

Multos săo os crticos que consideram a Enelde como uma espécie de decalque dos poemas homéricos. Nada mais injusto, entretanto, do que tal postura diante da epopéla de Virglio. Baseando-se nos textos gregos e utilizando-se de um roteiro semeIhante ao neles empregado, o poeta latino soube, contudo, tratar os demais temas de forma bastante pessoal. O confronto das duas "viagens" ao mundo dos mortos - a de Ulisses, na Odissếa, e a de Enélas, na Enelda - dá-nos uma prova daquilo que afirmamos.

A viagem de Ulisses é simples. Após chegar ao local determinado por Circe, to

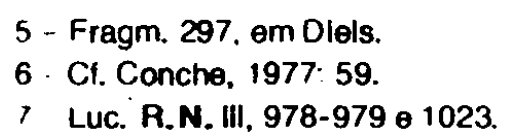


zer libaçס̃es rituais e pronunciar as oraçס̋es de praxe, o itaco vê as almas dos mortos surgirem em bando, vindas do fundo do Érebo. As personagens mortas são enumeradas por Ulisses, funcionando, talvez, a enumeração, como pretexto para o arrolamento de velhas lendas.

A viagem de Enéias, ao contrário, é bastante complexa, apresentando incidentes que até hoje intrigam os estudiosos.

Abre-se o livro VI da Eneida com a menção da chegada da armada troiana à regiăo de Cumas, na Itália (En VI, 1-2), e tal fato dá ensejo à primeira indagação: qual a razăo dessa escala?

Sabe-se que Cumas, antiga colónia de Cálcis, situava-se na extremidade norte do atual Golfo de Gaeta; o terreno vulcânico da regiâo se abre numa infinidade de galerias, poços, cavernas, cisternas, que excitam a imaginação do homem, fazendo-o ver, nesses acidentes naturais, possíveis meios de comunicaçăo com as entranhas da terra. Embora a cidade tenha sido fundada em época bastante posterior à da presumivel queda de Tróia - $\theta$, por conseguinte, de uma hipotética chegada de troianos ao litoral itálico -, Virglio pratica uma síncrese temporal e justifica a parada de Enéias em Cumas: o chefe dardânico ali se detivera com a intenção definida de consultar a Sibila Deffobe que exercia sua atividades no local (7-41).

A figura da sacerdotisa é construlda pelo poeta de forma especial. Não se trata de uma vidente comum, capaz apenas de antever o futuro, interpretando as palavras de Apolo. Alia-se a tal peculiaridade - comum as demais profetisas - 0 dom de abrir as portas do inferno, permitindo o acesso à regiáo dos mortos. Assim, ao lado de servir ao deus, serve também a Hécate, a tenebrosa deusa da feitiçaria, e conhece sobejamente a prática da magia e o trato com as ervas. Esse sincretismo de composição talvez seja a chave capaz de explicar alguns pontos do livro $\mathrm{VI}$ até hoje considerados obscuros.

Enéias, segundo Virglio, pretendia valer-se da dupla virtude da Sibila: graças a seus poderes conheceria o que estava por vir (42-101) e obteria autorizaçăo para penetrar na mansăo das almas, onde poderia avistar-se com o velho pai (102-123).

O assentimento da Sibila, todavia, em relação a esta última pretensão do troiano, se vincula a duas exigências: Enéias deveria colher um ramo de ouro, escondido num bosque, para oferecê-lo a Prosérpina, esposa de Plutão, $\theta$ teria de providenciar os funerais de um companheiro morto, Miseno, cuja morte era desconhecida de todos, mas cujo cadáver insepulto maculava a armada, por configurar-se nessa omissão um ato coletivo de impiedade (124-155).

A leitura da passagem coloca, de imediato, um problema diante do leitor. qual a relação entre as duas exigências e a visita de um ser vivo ao reino das sombras?

Embora até certo ponto discutiveis, os dois detalhes nos parecem igualmente importantes.

O sepultamento prescrito pela Sibila talvez se revista de valor simbólico. Segundo Plessis $\theta$ Lejay ${ }^{\circledR}$, de acordo com a velha crença itálica, para que as portas do Inferno 
se abrissem a fim de que o morto pudesse penetrar no reino das sombras, a alma deveria ser satisfeita com uma oferenda de sangue humano. Jean Bayet ${ }^{9}$ vê na laceração que as mulheres praticavam no rosto e nos seios durante a cerimónia fúnebre o vestfgio de um rito arcaico que prescrevia o sacriffcio de um ser humano em homenagem ao morto. A exigéncia da Sibila, ao pedir o sepultamento de Miseno, seria, pois, não apenas o cumprimento de uma prática piedosa que purificaria a amada, mas a dissimulaçăo de tal sacriffcio, repugnante, talvez, aos leitores da Eneida.

Por outro lado, a lenda do ramo de ouro é muito antiga na ltália e se aproxima de várias superstiçóes da Europa central $\theta$ ocidental, tendo alguma relação com as lendas que envolvem a colheita do visco selvagem, praticada por druidas nas florestas célticas. Sir George Frazer, em sua vasta obra The golden bough ${ }^{10}$, procura interpretá-la, estudando para tal fim práticas mágicas de todas as épocas, $\theta$, mesmo não tendo chegado a resultados cabais, alguma coisa pode ser depreendida de sua pesquisa. Existia em Nemi, como se sabe, um templo consagrado a Diana, no mesmo local onde, segundo a tradiçăo, Enéias encontrara o ramo de ouro. Propércio, na elegia II, xxxii, oferecenos uma rápida descrição desse templo. Realizavam-se ali, uma vez por ano, estranhas cerimónias nituais, revestidas de mistério. É Propércio ainda quem se refere a tais cerimónias que consistiam em procissóes notumas de que participavam pessoas que dançavam, corriam e brandiam archotes acesos (semelhantes, provavelmente, a ramos de ouro, pelo aspecto formal) ${ }^{11}$. Durante essas procissరes- $\theta$ aqui voltamos a valer-nos das informaçס̋es fornecidas por Frazer ${ }^{12}$ - jovens de ambos os sexos entregavam-se a sarabandas frenéticas, que culminavam năo raro num crime de sangue e num ato coletivo de prostituiçáo, durante o qual se invocava Diana ou Hécate, a divindade vinculada ao mundo dos mortos, que presidia à magia $\theta$ ao encantamento.

O ramo de ouro, portanto, na narrativa de Virglio, poderia também - como ocorre com o funeral de Miseno - ser um símbolo elegante para disfarçar as atividades orgiásticas - de que participavam apenas os iniciados - durante as quais a visão do sangue, a aspiração de ervas $\theta$ resinas queimadas, os excessos sexuais, o crime, a intoxicação, acabavam por propiciar terriveis visð̋es. Explica-se, assim, a presença do ramo de ouro, que até hoje permaneceu como um dado obscuro na narrativa virgiliana ${ }^{13}$

O mosaico parece completar-se. A entrada no Inferno - ou seja, a comunicaçăo do vivo com o espirito do morto, por meio de práticas mágicas que provocam visões exige, como se observa ainda hoje, em algumas cerimônias modernas, sangue e fogo; sacriffcio cruento e combustão de elementos tóxicos; o corpo de Miseno e o ramo de ouro.

A viagem de Enéias deixaria, pois, de ter características de viagem real e passaria a ser vista de outro ângulo: năo exatamente como um sonho (embora Jacques Per-

9 Bayet, 1976: 71.

10-Frazer, 1933: 1-8 e 146-167.

11 - Prop. II, xxxiii, 8-11.

12- Frazer, 1933: 1-9.

13 - Virgile, s/d: 504, n.6. 


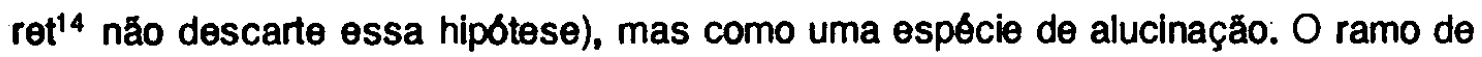
ouro, isto $\theta$, a combustáo de resinas especiais de um archote, produziria a intoxicaçăo. Os fenois contidos nos elementos aromáticos $\theta$ liberados pela queima provocariam as visőes. Virglio, como de resto o romano da época de Augusto, deveria ser bastante famllarizado com as propriedades dos alucinogenos, manipulados por feiticeiras $e$ associados de alguma forma ao culto de Hécate.

No decorrer da narrativa podemos observar que a viagem de Enélas tem muitas das características das "viagens" mentais, assim denominadas no jargáo dos toxic $\theta$ manos. Virglito escolhe um cenário real, $\theta$ fato, para nele instalar o chefe troiano, no infclo de sua peregrinaçăo. O lago Avemo, próximo ao qual se situava a caverna descrita, existe, na verdade, tem origem vulcânica e deve seu nome à forma grega Aornos (Aórnos = sem aves). Assim se chamou porque, por suas águas exalarem um odor extremamente desagradável em virtude dos compostos de enxofre em soluçăo, o lago năo atrala qualquer espécie de ave. A cavema, por sua vez, se situava num local chamado Dollola, utilizado como campo de sepulturas, onde foram encontrados urnas e jarroes (doliola) destinados a encerrar restos mortais humanos. Para Plessis e Lejay ${ }^{15}$, a soluçăo de Virglio, em bcálizar a porta do Inferno em lugar táo sinistro, $\theta$ bastante conveniente.

A viagem propriamente dita se inicia por um ritual. Enéias oferece sacriffcios aos deuses $\theta$ a Sibila invoca Hécate. Mais uma vez observamos a presença de "ingredientes" importantes: sangue de vitimas, fogo, "magia". A terra estremece com violência, ouve-se um estrondo $\dot{\theta}$ abre-se uma brecha no solo. Os căes uivam e uma sombra densa encobre o céu (242-272). Embora possamos considerar tais dados como símbolos que nos mostram que o processo alucinatório se iniciou, năo podemos deixar de observar que Virgllio joga com idélas usuais. Na poesia antiga, conquanto tivessem já alguns filosofos procurado explicar o fenómeno com alguma "cientificidade", os abalos sismicos såo muitas vezes associados à abertura das portas do inferno. Séneca, por exemplo, no primeiro episódio de As troianas, ao colocar na boca do arauto as palavras com que se refere à apariçåo de Aquiles, fá-lo mencionar as circunstâncias que precedem o fato: a terra ruglu com ruldo surdo e revolveu-se desde as profundezas; as árvores agitaram suas copas; os bosques troaram com imenso fragor e do cimo da montanha despencaram rochedos despedaçados. No próprio evangelho, curiosamente, Săo Mateus utiliza palavras semelhantes para descrever os fenomenos que sucederam a morte de Jesus: "E eis que o véu do templo se rasgou em duas partes, de alto a bal$x 0, \theta$ a terra tremeu, $\theta$ partiram-se as pedras, $\theta$ abriram-se as sepulturas" (Mat. 27, 50).

O interior do Inferno, descrito por Virglilo, $\theta$ bastante diferente do da fonte principal de que se valeu o poeta: 0 livro XI da Odisséla. Na epopéla homérica, as almas estão reunidas no Érebo. Ali se encontram "jovens esposas, homens jovens, velhos desgastados pela vida, virgens cujos coraçōes ainda não haviam conhecido o sofri-

141 - Virgile, 1978: 183.

15 - Virglle, s/d: 512, n. 2. 
mento, guerreiros feridos" Năo há separação por categorias ou classes; a situação de todos se assemelha.

O Infemo virgiliano é dividido em setores fato que sempre intrigou os estudiosos. Chega-se a ele após ter-se atravessado a floresta escura, um astro e um "vestibulum" onde se encontram algumas "divindades" Assim como Heslodo, na Teogonia (64), colocara as Graças e o Desejo à porta do Olimpo, Virglio valendo-se de uma criaçăo original, povoa o vestbulo do Inferno com numerosas personagens. Ali estăo a Tristeza, o Desejo de Vingança, as Doenças, a Velhice, o Medo, a Fome, a Indigência, a Morte, o Sofrimento, as Alegrias Más, o Sono, a Gũerra, a Noite, a Discórdia. As personificaçőes alegóricas são representadas como sombras pálidas que se esvaem. No meio do vestrbulo, uma enorme árvore estende seus ramos: é a árvore que abriga os Sonhos Falsos. O leitor se interroga: que são, afinal, os somnia uana a que se refere o poeta? Por que estão ali?

Interpreta-se, por vezes, a expressáo "sonhos falsos" como "sonhos irrealizáveis ou não realizados". Talvez pudéssemos propor outra forma de apreender o significado da expressăo. É possivel que "os sonhos verdadeiros", para Virglio, sejam os sonhos propriamente ditos, os que ocorrem à noite, durante o sono; "sonhos falsos" seriam, então, os provocados por agentes exteriores: as visర̃es e alucinaçס̋es.

Eståo presentes ainda, no "vestibulum" virgiliano, as figuras hibridas e prodigiosas dos Centauros, Cilas, Górgonas e Harpias e personagens năo menos monstruosas tais como Briareu, a Hidra de Lerna, a Quimera e Geriåo. Mais uma vez parece confirmar-se nossa suposição. Se a viagem de Enéias é uma "viagem mental" produzida por elemento químico, o "quadro" está perfeito. No inf́cio das alucinaçőes, as formas se esfumam, se apagam quando são provocadas, porém, por substâncias como a mescalina, a adrenalina, o ópio e congêneres, produzem deformaçర̋es visuais de caráter năo raro monstruoso.

Entre o "vestibulum" e o Inferno propriamente dito, corre o Aqueronte de águas tenebrosas, 0 caudaloso rio das paragens sombrias.

$\mathrm{Na}$ Odisséia, quando, ao final do livro $X$, Circe aconselha Ulisses a visitar o reino dos mortos, a deusa lhe mostra a direção a seguir. "Quando teu navio chegar à extremidade do Oceano, diz ela, "encontrarás uma praia $\theta$ os bosques sagrados de Perséfone". E continua: "Entra então, na úmida morada de Hades. $E$ a região onde se lançam no Aqueronte o Periflegetonte e o Cócito, cujas águas vêm do Estige".

No Infermo homérico, o Aqueronte se situa, pois, nos confins do Oceano; no virgiliano, na regiáo subterrânea de Cumas. Trata-se, entretanto, do mesmo no encachoeirado de águas barrentas e turvas. marcando a divisa do local reservado às sombras dos mortos.

Ao refenir-se ao rio. Virglio menciona a figura de Caronte, o barqueiro imundo que transporta as almas (295 304). Na Odisséia năo aparece tal personagem, embora a lembre Eurípides na tragédia Alceste. Após tel descrito Caronte, Virgnio retoma a tradiçáo homérica (Od XI, 72 ss.), segundo a qual os mortos sem sepultura năo têm direito ao descanso eterno, e fala da multidáo de almas que deseja atravessar o rio e é pos- 
ta de lado pelo velho barqueiro, devendo aguardar cem anos para poder passar. Como costuma proceder, Virgnio mescla duas tradiçס̋es; aqui ele combina os dados extraldos da lenda épica com uma idéia emprestada, provavelmente, da filosofia pitagórica.

Dois estratagemas usados por Enéias e pela Sibila chamam a atençăo do leitor. Para conseguir entrar no barco de Caronte, a feiticeira mostra-lhe o ramo de ouro $\theta$ para tranquilizar Cérbero, o guardiấo do Inferno, oferece-lhe um bolo soporffero, feito de mel $\theta$ de grãos (384-425).

Mais uma vez parece comprovar-se nossa suposiçăo. Exibir o ramo a Caronte corresponde a submetê-10 a um poder externo; o ramo năo $\theta$ apẹnas uma espécie de passaporte, como o pretende Jacques Perret ${ }^{16}$. É um objeto que, como os tóxicos, tem o poder de mudar o comportamento das pessoas. Quanto ao bolo oferecido a Cérbero, sua natureza $\theta$ explicita $\theta$ atesta 0 conhecimento de Virgnio no que diz respeito a sonfferos $\theta$ entorpecentes: os gráos com os quais fora preparado continham substâncias especiais, capazes de provocar um sono artificial.

Acompanhando-se, a seguiir, a peregrinação de Enéias, pelo obscuro mundo das trevas, percebe-se que o interior do Inferno virgiliano é bastante peculiar, subdividindose em quatro diferentes regibes. A primeira é reservada aos que morreram antes que se cumprisse seu destino: criancinhas que choramingam numa espécie de limbo, suicidas, pessoas vitimadas pelo amor, soldados feridos mortalmente no calor das batalhas (426-547). Todos vêem o tempo eterno arrastar-se e ninguém se furta a um julgamento preliminar. E aqui uma curlosidade: Virgnio transforma Minos numa espécie de "quaesitor", tipicamente romano, auxiliado em suas funçర̋es legais por um corpo de jurados.

A segunda regiáo 6 o Tártaro, onde os criminosos imperdoáveis cumprem penalidades sem fim. A descrição do lugar apresenta pontos comuns com a concepção bßblica do inferno, registrada nas páginas do Novo Testamento. Enéias vê um lugar fortificado, cercado por um ro em chamas, fechado por uma porta indestrutivel que deixa ouvir, do interior, o ruido do choro, dos açoites, das correntes de ferro, arrastadas pelo chå (548-627). As palavras do poeta equivalem aquelas com que São Mateus, citando os dizeres de Jesus, refere-se ao inferno cristăo: "Assim como é colhida a cizânia, $\theta$ queimada no fogo, assim acontecerá no fim dos séculos. O filho do homem enviará seus anjos, $\theta$ trarăo do seu reino todos os escândalos $\theta$ os que praticam iniqüidade. $E$ lançá-los-áo na formalha de fogo. All haverá choro e ranger de dentes" (Mat. 13,40-42).

A próprla guardiâ do Tártaro virgiliano, a grande hidra de cinqüenta bocas, ểmula, em seu aspecto horripilante, da besta cor de escarlate, com sete cabeças e dez chifres, descrita por Săo Joâo, nas páginas enigmáticas do Apocalipse (Apocal.17,3).

Após a reglăo dos suplícios, no meio do Infemo, encontra-se a morada de Plutăo - Proserpina. Enélas, segundo Virgnio, detém-se ali por um momento, asperge seu corpo com água fresca e coloca o ramo de ouro no portal da entrada. É o clímax da "visão" do principe troiano; inicia-se o declínio (628-636).

Enélas jấ nấo se submete mais ao sortilégio do misterioso ramo e tem condiçőes

16-Virglle, 1978: 47 A, n. 1. 
de encontrar a paz almejada, a paz de que os Campos Elísios, terceira regiăo da casa das almas, representam provavelmente o simbolo.

A descrição virgiliana desse local tranqüilo e ameno, destinado a receber os bons, tem algum sabor pindárico, mas revela também influência de Homero e Heslodo ${ }^{17}$ Estende-se, agora, diante de nós, a paisagem contemplada pelo teucro: um vergel agradável e fresco, repleto de árvores, povoados de jovens que dançam ou se exercitam em lutas esportivas. Nesse "paraiso" está Orfeu, o citarista divino, bem como as almas dos antigos fundadores da raça troiana, os soldados que morreram pela pátria, os sacerdotes castos, os poetas, os inventores, as pessoas que praticaram boas açóes. É ali que permanece Anquises, a razáo aparente da viagem de Enéias pelos dominios dos mortos (628-702).

Distanciada dos Campos Ellisios e deles separada pelo rio Letes, localiza-se a quarta região do império de Plutáo: um bosque coberto de árvores frondosas, onde uma imensa multidão de sombras se aproxima do rio. Para satisfazer à curiosidade do filho, Anquises fala do destino que aguarda tais seres: são eles os esplritos dos mortos que esperam o momento de cumprir nova sina, reencamando-se em outros corpos e voltando a viver (713-885). A exposiçăo de Anquises, com a explicaçăo sobre a origem das espécies, a partir de uma energia Ínea, revela influência da filosofia estóica; as referências aos castigos sofridos pelas almas impuras, numa espécie de purgatório, $\theta$ as alusరes à metempsicose mostram conhecimento da doutrina pitagórica e órica ou de idéias já exploradas por Pindaro e Platão ${ }^{18}$.

Náo temos elementos para saber se Virglio partilhava de alguma dessas crenças. Talvez em seu procedimento se possa ver unaa tendéncia alexandrina de demostração de enudiçăo ou mesmo um artificio para que Anquises pudesse apresentar a Enéias, numa fusăo atemporal de passado, presente e futuro, as almas que se incorporariam em ilustres personagens da história romana.

Depols de antever o porvir da cidade e conhecer os herois que ainda estavam por nascer, Enéias ouve os últimos conselhos do pal e prepara-se para regressar à vit da (752-892). Já quase no final do livro há uma referência às duas portas do Sonho, por uma das quais o troiano deverá sair (893-898). Por que ter-se-ja referido o poeta a portas do Sonho, pelas quais se sal do Inferno? Por que distinguir a porta dos Sonhos Falsos da dos Sonhos Verdadeiros? Por que fazer o herói sair pela porta dos Sonhos Falsos? É verdade que Virglio, ao falar das portas, retoma uma tradiçăo homérica. Pené lope, porém, quando, na Odisséia (XIX, 560 ss.), se refere às portas do sonho, está realmente falando de sonhos. Aqui, as portas do Sonho sáo meios para que se saia do Infemo. Enélas sonhara, portanto: salra de um sonho falso - diferente dos que ocorrem à noite, durante o sono - para retomar à vida, dirigir-se aos navios e rever os companheiros.

17 - Pind. Olimp. 2, lo9; Od N, 576 ss.; Hes. T.D. 170

18 - Cf. Pind. Olimp. 2,70 e Platáo, Fódon, Fedroe República 
Permitindo tantas leituras e construído com tão grande número de pormenores talvez até mesmo por essa razáo -, o texto de Virglío dá nfíida impressáo de pura composiçăo estética, talvez com algum valor metafórico-alegórico. Dificilmente poderiámos dizer que nele há indicios de correspondência a uma crença religiosa.É um trabalho artístico, sem dúvida, mas de caracterlsticas que nos parecem acentuadamente artificiais. Virgllio se valeu da viagem de Enéias aos domínios de Plutão para dizer muita coisa, inclusive para redimensionar a figura do chefe troiano (joguete dos deuses até entáo e heról agente após o retorno das sombras) e fazer uma das mais belas exaltaçర̇es a Roma, esboçando, pela antevisão do futuro da urbs, a história de seus feitos grandiosos.

A leitura de textos dos demais poetas da época de Augusto parece confirmar a Idéia de que o mito do Inferno tỉnha, sobretudo, nas obras literárias, uma funçăo ornamental. Cada poeta o interpretou à sua maneira, dando năo raro um cunho bastante pessoal a interpretação. Horácio, provavelmente mais interessado em documentar fatos do-dia-dia, exaltando os prazeres da vida, menciona rapidamente o reino dos mortos, na Ode 11,13 . O ton com que se refere ao Inferno, porém, guarda a mesma irreverência, irónica e jocosa, que marcou grande parte de suas obras. Fala ele, inicialmente, do fato de quase ter sido atingido por uma árvore que calra e de, por pouco, năo ter Ido fazer companhila a Alceu e Safo, na morada infernal. Se tivesse morrido, entretanto, poderia verificar que as cançסes de tăo importante plêiade de liricos distrairiam Cérbero, acalmariam as Fúrias e permitiriam aos condenados que se esquecessem, por momentos, dos terriveis sofrimentos que são obrigados a suportar.

Tibub, o doce poeta das elegias amorosas, também apresenta em um de seus poemas uma pequena descriçăo do mundo das sombras (Tib. I,iii). Projetando-se na figura do eu-narrador, o poeta lamenta sua triste sina: afastara-se da pátria, adoecera, sentia-se morrer. Consola-se, porém na esperança de que será destinado aos Campos Elisios, pois que fora sempre dócil ao amor. Vênus certamente lhe servirá de guia, conduzindo-o à regiăo de gozos e prazeres. Como o "paralso" de Virglio, também o de Tibulo revela influência de Pindaro, nos elementos que ostenta: floresce em rosas e se pertuma com o olor dos cinamomos; oa pássaros cantam, fazendo coro às cançőes dos jovens que dançam ou se entregam a jogos amorosos. "Ali se encontram", diz Tibulo, "todos aqueles de quem a morte se aproximou quando estavam amando e eles trazem coroas de murta em suas belas cabeleiras". Opరe-se ao pacfico local, cheio de doçura $\theta$ encanto, a mansáo maldita dos criminosos, escura $\theta$ sombria, cercada de rios caudalosos, que fervem $\theta$ rugem. Ali estão Tisfone e Cébero $\theta$ as almas que sofrem merecidas penas: Ixiáo $\theta$ desconjuntado na roda de tortura. Tftio oferece as viceras às aves de rapina; Tântalo se aproxima sedento das águas que se afastam. as Danaides enchem, continuamente, o tonel sem fundo. Numa imprecação. que revela desejo de paz, Tibulo almeja que para lá sejam conduzidos os que lhe auguraram honras militares, violentando seu amor.

Contemporâneo de Tibulo, empregando freqüentemente o tema da morte em suas elegias, valendo-se com insistência de alusões mitológicas, Propércio se refere, muitas 
vezes, no correr dos poemas, ao tenebroso mundo das sombras. Năo chega, entretando, a compor uma descrição do inferno. Vale-se dos elementos do mito para ilustrar idéias e delinear uma posição. Na elegia III. v por exemplo. numa atitude muito sua. procura mostrar a pouca importâncla das nonras e riquezas e fala da igualdade de todos. após a morte. "C vencedor se mistura as sombras do vencidos", diz ele. "Tu, Jugurta, que toste apnsıonado, sentas-te ao lado de Mário, o cônsul. Creso da Lidia - o ricaço famoso - fica perto de Iro, o mendigo de Duliquiăo." E noutro passo um pouco depois, ao referir-se à morte de Marcelo, sobrinho e genro de Augusto, confirma a mesma idéla que antes expressara: “O caminho é nuim, mas deve ser percorrido por todos; por todos têm de ser aplacadas as bocas ladrantes do căo; a barca do velho sinistro tem de ser escalada por todos" (III, xviii).

Embora nas elegias IV, vii e IV, xi o poeta ceda a palavra a mulheres já mortas, pondo-Ihes na boca alusరos ao Inferno, năo é sempre que temos a impressăo de que ele admitia como real a existência de um lugar reservado a abrigar as almas. Na elegia III,v -. Propercio se questiona sobre a veracidade do mito. Existem, realmente, deuses debaixo da terra? Vive ali Tisffone enfurecida, com sua cabeleira de serpentes? Punem-se os criminosos? Cérbero se posta à entrada, como um guarda ameaçador? Ou tudo isso nåo passa de uma fábula inventada para amedrontar as pessoas infelizes. nenhum temor podendo existir após a morte?

Como seus antecessores, Ovldio também se refere ao Inferno em sua poesia. Ao descreve-lo, entretanto, imprime-lhe características bastante pessoais.

O gosto alexandrino pelo requinte da forma fá-lo pintar, num passo das Metamorfoses (Met. IV, 432-463), um retrato elaborado dos domínios de Plutáo. A preocupaçáo com a vida citadina, que the conferiu foros de poeta urbano, impele-o a conceber o reino dos mortos como uma grande cidade à qual se chega por um caminho em declive, ensombrado de teixos, enevoado, silencioso e frio. A "cidade" infernal é réplica das cidades reais. Embora exangues, sem corpo e sem ossos, as almas dos mortos se entregam a afazeres que refletem os da vida: freqüentam o foro e o palácio do soberano, praticam offcios, receberm castigos. As próprias divindades que ali estăo têm multo de humano. Juno, chegando em visita à mansăo dos mortos, é o protótipo da mulher impulsiva e temperamental, que semeia desordem por onde passa; as Fúrias, à maneira, talvez, das damas de Roma, penteiam vaidosamente, à porta do cárcere eterno, as serpentes negras que thes compoem as cabeleiras. É sem dúvida, um texto bem proprio da lavra de um poeta que, náo satisfelto em compor uma Arte de Amar, onde se detivera nas sutilezas empregadas nas conquistas amorosas, escrevera ainda, para uma sociedade mundana. elegante $\theta$ fútil, um pequeno tratado, condensando "receltas" de beleza ${ }^{19}$

No século I de nossa era, os poetas continuam a insistir no uso do tema do Inferno. Sêneca, por várias vezes, retoma o velho mito, nas tragédias. Em Fedra, mostranos Teseu recém-chegado da regiáo dos mortos: no prólogo de A loucura de Hêrcu-

19 - De medicamine taciel 
les, apresenta-nos uma Juno cheia de odio, relembrando as peripécias do herói e enfatzando a viagem por ele feita ao reino de Plutăo; no segundo episódio de Édipa, coloca nas palavras de Creonte a descrição do aparecimento do espectro ensangüentado de Laio, saldo diretamente das profundezas do Érebo; no prólogo de Tiestes, faz a sombra de Tântalo referir-se aos horrores do Tártaro. Em As Trolanas, porém, apesar de, no primeiro episodio, construir a figura de um arauto que descreve a apariçăo de um fantasma, no segundo cântico coral adota um procedimento singular - 0 coro das mulheres de Tróla póe em dúvida a sobrevida e chega a uma conclusăo de nítido sabor epicurista: "O Ténaro, reino submetido a um senhor cruel, e Cérbero; o guardião obediente a um dono inflexivel, săo palavras inofensivas, de som vazio, são fábulas semelhantes aos pesadelos. Perguntas: em que lugar permanecerás depois da morte? No mesmo em que permanecem aqueles que não nasceram".

Juvenal, por seu tumo, escrevendo uma de suas sátiras já ao final do século, refere-se à descrença dos romanos no que diz respeito ao mito em questăo: "Nem os rapazinhos, a não ser aqueles que ainda năo freqüentam as termas, acreditam que existem Manes, ou reinos subterrâneos, ou negras rãs na garganta do Estige e um barquinho que transporta tantos milhares de almas" (Sat. II, 149-152).

Sêneca $\theta$ Juvenal vivem no momento em que o cristianismo se dissemina em Roma, trazendo respostas a problemas existenciais e propondo a Vida Etema como razăo da vida terrena. A aceitaçăo das novas idélas, por um número cada vez maior de romanos, $\theta$ prova do enfraquecimento dos velhos mitos, como crenças. A ficção de tal maneira os deformara, dando-lhes contornos diferentes a cada mençăo, $\theta$ as antigas religibes se haviam tomado a tal ponto insatisfatórias que a nova doutrina se implantou, correspondendo aos anseios de parte significativa do povo. Mais uma vez a mansåo das almas val ser posta em destaque, representando o coroamento da vida. Mais uma vez os escritores văo fornecer-nos imagens fictfcias desse novo mundo, ora povoado de anjos $\theta$ santos, entregues às alegrias da contemplaçăo divina, ora regurgitando de demónios e condenados a queimar pelos séculos afora a culpa de seus pecados.

Detemo-nos, entáo, diante de tudo isso, e propomo-nos aquelas questoes que inquibtaram, no passado, tantos filospfos e tantos poetas: existirá algum tipo de vida após a morte do corpo? Ou tudo aquilo que se diz do além náo passa de palavras inventadas, com obscuras intençбos?

As respostas serão fatalmente divergentes. Mas os textos antigos al estão, com sua beleza $\theta$ sua poesia, permitindo infinitas leituras $\theta$ oferecendo pretextos para as mais diversas espécies de investigaçăo. 


\section{BIBLIOGRAFIA}

Banton, M., Anthropological approaches to the study of religions. Edinburgh, 1966.

Bayet, J., La réligion romaine - histoire politique et psychologique. Paris, Payot, 1976.

Bßblia Sagrada (trad. da Vulgata $\theta$ anot. pelo Pe. Matos Soares). S.P., Ed. Paulinas, 1953.

Boissier, G., La réligion romaine d'Auguste aux Antonins. 7a. ed. Paris, s/d, Vol.I.

Challaye, F., Pequena história das grandes religibes. (trad. de A. Silveira). S.Pau10, IBRASA, 1940.

Conche, M., Épicure - lettres et maximes. Villers-sur-Mer, Mégare, 1977.

Diels, Die Fragmente der Vorsokratiker. Berlim, 1910-1912.

Frazer, Sir George, The golden bough - a study in magic and religion London, Macmillan, 1933.

Goody, J., Death, property and the ancestors. Calif., Stanford, 1962.

Hésiode, Travaux et jours (avec notes). Paris, 1909.

Hesiodo, Teogonia (est. e trad. de J. Torrano). S.P., M.Ohno, 1981.

Homère, L'Odysséa. (trad. de M. Dufour e J. Raison). Paris, Garnier, 1934.

Horace, Oeuvres (com est. introd. e notas de F. Plessis e P. Léjay). Paris, Haachette, 1917.

Lucrèce, De la nature (texte et. et trad. par A. Emout). 9a. ed. Paris, Les Belles Lettres, 1955.

Ovide, L'art d'aimer (texte et. et trad. par $H$. Bornecque). Paris, Les Belles Letres, 1967.

-_-- Les Métamorphoses (texte et et trad. par G. Lafaye). Parts, Les Belles Lettres, 1962.

-.- Les remedes a l'amour (texte et. et trad. par H. Bomecque). Paris, Les Bellés Lettres, 1967.

Platon, La république. In Oeuvres complètes V e VI (texte et et trad. par E. Chambry). Paris, Les Belles Lettres, 1985.

--- Phédon. In Oeuvres complètes IV. (texte et. et trad. par L. Robln) Parls, Les Belles Lettres, 1967.

Phedre. In Oeuvres complètes IV (texte et. et trad. par. L. Robin) Paris, Les Belles Lettres, 1970.

Pindare, Olympiques (t. et parA . Puech). Paris, Les Belles Lettres, 1971.

Properce, Élegies (texte et. et trad. par D. Paganelli) 4a. ed. Paris, Les Belles Lettres, 1970.

Tibulle, Elegies (texte et. et trad. par M. Ponchont). 7a. ed. Paris, Les Belles Lettres, 1968. 
Sénèque, Tragédies (texte et et trad. par L. Hermann). 3a. ed. Paris, Les Belles Lettres, 1967.

Virglie, Oeuvres (intr. e notas de F. Plessis e P. Lejay) Paris, Hachette, s/d.

Virgile, Énéide V-VIII (texte et. et trad. par J. Perret). Paris. Les Belles Lettres. 1978 